Article

\title{
Drivers of Development in a Romanian Context: An Empirical Study of the Potential Impact of Religiosity and Individual Values on Core Human Rights Relevant to the United Nations' Agenda 2030
}

\author{
Silviu E. Rogobete ${ }^{1, *}$ and Ligia Pețan ${ }^{2}$ \\ 1 Department of Political Science, West University of Timisoara, 300223 Timișoara, Romania \\ 2 Independent Researcher, 300223 Timișoara, Romania; ligia.petan@yahoo.com \\ * Correspondence: Silviu.rogobete@e-uvt.ro
}

Received: 28 October 2020; Accepted: 18 November 2020; Published: 23 November 2020

\begin{abstract}
The aim of this study is to analyse the complex interplay between religiosity, individual values, and support for human rights relevant to development, in a Romanian context marked by high levels of religiosity and low levels of socioeconomic development. The study employs a quantitative empirical research project involving high school students (N-681) in all the capital cities of the regional development areas of Romania. The results of hierarchical multiple regression analysis indicate that some dimensions of religiosity (religious belief and faith) are positive predictors of support for socioeconomic rights, universalism, and human dignity, and thus are conducive to sustainable development attitudes and practices. However, other dimensions, such as theism, positively predict traditionalism, while negatively predicting universalism, which may indicate a lower propensity towards supporting development. Hence, it can be inferred that for this sample, religiosity has a real but limited role in supporting some human rights and individual values conducive to a culture of development relevant to the United Nations (UN) 2030 Agenda. Individual values such as self-direction and universalism seem to play a more important role.
\end{abstract}

Keywords: religion; human rights; individual values; development; Romania; youth

\section{Introduction}

Recent data show that Romania is the most religious among 34 European countries (Evans and Baronavski 2018), as well as one of the least developed European Union member states (UN Human Development Reports 2019). Although a signatory of the United Nations (UN) 2030 Agenda for Sustainable Development, and therefore committed to reach its goals, Romania presently finds itself quite distant from realizing them. Recent research has shown that the implementation status of sustainable development goals (SDGs) is sub-optimal, forecasting that only 40 of the 107 indicators analysed will be reaching EU average values by 2030 (Firoiu et al. 2019). However, it also emphasises that, if the right measures are taken, Romania can still remain on the path to development. Although religion seems to play an important role in Romanian society and culture, empirical research assessing the influence of people's religiosity on their attitudes and behaviour towards others and the environment in which they live is lacking. Moreover, the success of development plans and strategies for the near future will significantly rely on the current younger generation. As previous results indicate, the Romanian young people also show significantly high levels of religiosity (Rogobete and Reisz 2018). The question addressed in this study therefore is whether their religiosity can be a predictor for development attitudes and predispositions. 
Thus, building on empirical data collected from questionnaires completed by upper age students (N-681) in high schools of all the capital cities of the Romanian development regions as defined by the EU, this study aims to understand and unpack the role of religiosity (beliefs and practice) in relation to support for human dignity, human rights and core individual values central to development. Existing literature shows that during adolescence, individuals are in search of personal values, beliefs, and roles, trying to develop a coherent sense of self and personal identity (Erikson and Erikson 1998). The current study provides new data and results useful for identifying ways in which religiosity influences personal values and respect for human rights conducive to development in a specific sector of the rising generation of Romania.

The concept of development is being used in this work in the general sense given by the UN's 1987 Brundtland Commission Report [1987], as "[development] that meets the needs of the present without compromising the ability of future generations to meet their own needs" (Brundtland 1987). This concept is at the centre of the UN's Agenda 2030 (UN 2030 Agenda 2015). Academic literature quite widely backs the idea that the key to development is a strong culture of support for human rights, and value-based predispositions towards the fulfilment of sustainable developmental goals (Sen 2000). The current research project considers drivers or attitudes conducive to development to be support for human dignity, support for human rights, and individual values (self-direction, universalism). Given the complexity of the concepts involved, the first part of this paper maps their dynamic interconnections by a review of the relevant literature.

\subsection{Religion, Values and Development}

One possible starting point is the contested place played by religion (Rakodi 2015). In fact, for most of the 20th century, dominated by secularism, religion was seen, in the former communist atheistic regimes, as an outright "enemy", while in the West, it was perceived as an unimportant contributor to the public sphere, and thus was pushed into the private realm. The Weberian "dis-enchanting" of the world was taken as a given certainty with the dawn of modernity (Berger 1969). This situation is significantly changing, to the point where the same authors are often, based on new empirical data, reconsidering their evaluations (Berger 1999). In countries such as Romania, which were until 1989 part of the Eastern communist bloc, all three aspects of life, religion, human rights and development, were contested (Kolakovski 1983; Tismăneanu 2003; Rogobete and Reisz 2018).

However, the dramatic failure of the atheist-totalitarian political regime in Romania led to a rather unexpected return to religion as well as to a growing movement towards embracing democracy and human rights. In regard to religiosity, both in terms of practice and belief, Romania is the most religious country in Europe. Currently, $98 \%$ of the population claims to belong to a Christian denomination ( $87 \%$ Eastern Orthodox), 95\% of the population believe in God, 55\% of Romanian adults are "highly religious", 50\% say "religion is very important in their lives", 50\% attend church at least monthly, $44 \%$ say they pray daily and $64 \%$ say they "believe in God with absolute certainty" (Evans and Baronavski 2018). Earlier studies have shown that the young people whose attitudes are surveyed in this work also display high levels of religious practice and belief, with $81 \%$ of the sample considering themselves as believers, $88 \%$ praying regularly, and $44 \%$ attending religious services at least once a month (Rogobete and Reisz 2018). Such figures are higher than in other European nations, as shown by results of comparative studies based on the same data (Unser et al. 2018; Breskaya et al. 2019; Breskaya and Rogobete 2020). Hence, in this study too, religiosity will be assessed both in regard to its content/substance, and its various forms of manifestation. In other words, we are interested at looking into both the content of religious beliefs (faith in general, faith in God in particular) and religious practice (frequency of prayer and religious service attendance) of the subjects involved in the study.

Academic assessments of the role of religion in development in the Romanian context are limited (Lazar 2011). Relevant for the current study is a doctoral thesis (Bates 2013), which offers a solid conceptual analysis of the ways in which core teachings of the majority Eastern Orthodox tradition 
are compatible with development studies. Generally following Deneulin and Bano's (2009) approach to the relationship between religion and development studies, it shows how some key aspects of Orthodox theology, such as phronesis (practical wisdom) or its Trinitarian (communitarian) theological anthropology, can contribute to a conceptual framework for human development. Francis Fukuyama (2014) endorsed the research, highlighting the strong connections that can be explored between Eastern Orthodoxy and development studies, entailing an image of the human person as a morally responsible agent called to engage in human development, "which is to say a process of understanding and appropriately developing all of nature's potentials (biological, sociological, etc.), and for the benefit of all".

In the last two decades, there has been a growing volume of academic literature with religion as its main research focus in relation to development and sustainability (Alkire 2006; Leal-Filho et al. 2019). Some writers emphasise the function of religion in development (Haynes 2007; Tomalin et al. 2019), others focus on the content of religious faiths (Deneulin and Bano 2009; Narayanan 2013; Leal-Filho et al. 2019), yet others assess and acknowledge cooperation between religious leaders and agencies, and secular development actors on the ground (Berry 2014; Tomalin 2015). Others, however, emphasise the irrelevance of religion (Ekardt 2020), or outright incompatibilities between religion and development (Juergensmeyer 2000).

In one recent comprehensive exploration of the role of religion and the "faith actors" in the fulfilment of the 2030 Agenda of the sustainable development goals, the authors confirmed the "turn to religion" in global development policy and practice from the early 2000s (Tomalin et al. 2019). Their study offers an in-depth evaluation of the role that faith actors have played in the elaboration and implementation of the SDGs.

Looking at the content of religious practice and belief, Deneulin and Bano (2009) challenged contemporary views that religion remains a private affair. Assessing core beliefs and practices of Christians and Muslims around the world, they argued that for religious persons and for their communities, alleviating poverty, and promoting social justice and equality are intrinsic acts and expressions of faith. In other words, it is not only the function of religion that counts in development studies but also the content and the practice of religious beliefs that can result in acts supportive to development. Religious people concerned with development do so in a way informed by who they are and what they believe in: "religion infuses all aspects (and decisions) of their lives, and this has implications for the way they understand what development processes and outcomes ought to be" (Deneulin and Bano 2009, p. 6). Their book highlights the role of religion in development, emphasizing that "religion forms people's values and what counts as legitimate development" (Deneulin and Bano 2009, p. 28).

This argument takes further Amartya Sen's (1999) view of development as based not so much on practices and institutions, as on the free agency and values people deeply hold. Although Sen does not make references to religion, his central ideas, developed around the concept of the capability approach, place individual and collective values at centre stage for human development. Religion, by its nature, provides a metaphysical ground for intrinsic values that often go beyond such wellbeing dimensions, such as education or health, perceived in largely functional extrinsic terms. Therefore, religion should not be "viewed instrumentally but recognized as shaping peoples' deeply held moral values and what they see as desirable and worthy of pursuit" (Deneulin and Bano 2009, p. 8). Hence, it is important to understand and further enquire into the ways in which religion is capable of shaping individual values, which in turn, are relevant resources to a sustainable development agenda.

Narayanan (2013) applies a similar approach, further analysing the complex connections between religion and sustainable development. She argues that, particularly in contexts in which religion is problematic or plays a crucial role, "it is even more important for sustainable development to engage actively and critically with it, to retrieve religion's life-enhancing potential" (Narayanan 2013, p. 132). Furthermore, she highlights that religion can have an influential role in determining socioeconomic sustainability. Her analysis emphasises three important dimensions. First, religion provides universal 
values, which can become a resource for the knowledge and practice of sustainable development. Second, religion has a role in sustainable development, by providing a solid ground for the human self and its own development. For instance, religion can provide a set of individual values, such as unconditioned benevolence or self-sacrifice. Thirdly, a strong notion of the self can be a powerful resource for socioeconomic activism targeting a sustainable agenda. Assessing religiosity, its role in defining who we are, what we value most, and what ultimately motivates us to act, becomes a relevant task in assessing dispositions towards a sustainable future. Religiosity can thus contribute to a person's development, alongside other general aspects intrinsically valued by individuals, such as safety, health, or self-direction (Narayanan 2013).

The links between religion and individual values, particularly in relation to sustainable development, however, are still underexplored (Ives and Kidwell 2019). Based on Schwartz's (1992, 1994) earlier research on universal individual value systems, Ives and Kidwell (2019) define religion as a strong identity provider, and an important player in establishing and shaping values and norms. This, in turn, can be instrumental in providing the right ingredients for sustainable development. Research findings have pointed out that the religiosity of adherents to all major Christian denominations and to Jewish faith correlated positively with benevolence, empathy, traditionalism, conformity and security values, and negatively with power, achievement, hedonism, stimulation, and self-direction (Schwartz and Huismans 1995). Another relevant study, based on Schwartz's model, is a meta-analysis that showed that religious people scored highly on values that promote conservation of social and individual order, along with limited self-transcendence (i.e., benevolence, but not universalism) (Saroglou et al. 2004). However, Ives and Kidwell (2019) rightly argue that a deeper understanding of the ways in which values are influenced by religion, therefore making them compatible with sustainable outcomes, requires a better knowledge of the wider contexts in which they operate.

\subsection{Religion, Human Rights and Sustainable Development}

Human rights and the right to development have been affirmed as intrinsically linked — the right to development is a fundamental human right (Vienna Declaration 1993). A careful assessment of the UN 2030 Agenda for Sustainable Development also offers ample proof that the right to development remains central to the project of human rights, yet in the new context of increasing globalization, it moves forward to include issues of sustainability. Moreover, human dignity is to be found at the foundation of all discourse and practice of the UN and the EU agendas on human rights and development. Dignity is the legal concept underlying all other human rights (Grimm 2013). Hence, human rights and human dignity, seen in a global context, remain the main underlying concepts, the raison d'etre, of the UN 2030 Agenda. Its preamble makes both of these points explicitly clear, while a careful analysis shows how human rights, particularly socioeconomic rights, can be found enshrined in all of its 17 goals.

Conceptually, links between human capabilities, human agency and dignity, freedom and the pursuit of safety and happiness enshrined in human rights and human development have been explored by Amartya Sen (1982, 2004, 2005) and Martha Nussbaum (2003). As a normative theoretical framework, "the capability approach", launched by Sen (1980), starts from stating that the right of a person to pursue and to achieve well-being is a fundamental moral question. Going beyond utilitarianism and equalitarianism, such a right must, however, include both concrete access to resources, and the individual's real capabilities to reach them. Moreover, the pursuit for well-being starts from the individual's concrete capabilities, centred on, and informed by what she has strong reasons to value. In other words, being capable to live "free from fear" and "free from want" means being capable to "be" and to "have" what one values most. As such, human rights are intrinsically connected with human development and human dignity. Empirically, such theoretical framework led to a growing literature relating human rights and development, a relevant example being the Economic and social rights fulfilment index used to measure human rights support through the lens of socioeconomic developmental measures (Fukuda-Parr et al. 2009; Randolph et al. 2010). Hence, it displays the relevance of support for socioeconomic rights in development. 
In regard to religion and human rights, previous studies on the same sample of participants as the current one, based on different variables, have shown that belief in God and attendance of religious services have a limited negative effect on attitudes to certain judicial rights, but no effect for political rights (Rogobete and Reisz 2018). In addition, assessing whether the religiosity of the students, or the self-acquired socio-political and psychological traits have a more significant influence on their support for socioeconomic rights, the findings show the most significant issues supporting socio-economic rights to be: the respondents' belief in God, their view that politicians may consult religious leaders about ethical issues, and their high levels of empathy (Rogobete and Vitelar 2020). The current study intends to take these inquiries further, assessing the role religiosity and individual values play in generating attitudes relevant to sustainable development (i.e., support for human rights and human dignity).

Gas-Aixendri and Albareda-Tiana (2019) use religion as an independent variable, while measuring commitment to human rights values and actions within a sustainable development framework. Their study shows that an increased support for socioeconomic human rights, using religion as an independent variable, can be translated into advancing a development agenda. Moreover, to prove such development sustainable, they argue that the enquiry needs to address some concrete concerns for sustainability, such as care for the environment (universalism).

However, some scholars have a rather critical view of the interplay between human rights and sustainable development, describing them as different conceptual constructs with often contrasting agendas (Donnelly 1999). Other scholars question the compatibility between promoting important sustainable goals, such as long-time environmental responsibilities, while potentially harming such rights as the right to self-determination, free movement, or the right to work in the present (Grimm 2013).

Finally, the present study seeks to inquire if religiosity can be a predictor for support for human rights, values, and attitudes, conducive to sustainable development. Thus, the study includes the following steps: (1) assessing the impact of religiosity (beliefs and practice) on participants' individual values, (2) analysing how religiosity influences respect for human dignity (merit, moral and intrinsic), (3) evaluating the impact of religiosity on and attitudes to an extensive range of human rights (civil, political, judicial, social and economic), while at the same time considering the potential influence of individual values and views of moral dignity. The study finds that, for this sample, religiosity has a real but limited impact in supporting and promoting a culture of sustainable development as enshrined in the UN 2030 Agenda. More support was found in the realm of the respondents' individual values related to self-direction and universalism.

\section{Materials and Methods}

This section describes and discusses the design of the study, sampling procedure and the instruments used.

\subsection{Research Procedure, Sample and Ethics Statement}

The current work is based on the data collected by the authors in September-December 2015 in Romania. As part of the international research project Religion and Human Rights (RHR 2011-2019), the written survey used is a standardized questionnaire (SQ1 questionnaire), which was translated into Romanian. The participants were 681 high school students (N-661 remained valid) from the capital cities of the development regions of Romania: Timisoara, Cluj-Napoca, Iasi, Constanta, Sibiu, Ploiesti, Craiova, and Bucharest, the country's capital. Students answered the online questionnaire in one sitting, under the supervision of their educational staff. In terms of age, $88.7 \%$ of respondents were between 16-18 years old, while the sample is almost equally split among male and female participants: $51 \%$ male and $49 \%$ female. Participation in research was voluntary, totally anonymous and based on informed consent. 
Ethics Statement

The research conducted in the present study is in full compliance with all standards of good scientific practice and ethical codes expressed in the documents of the German Science Foundation. The confirmation letter for research ethical codes compliance regarding the International Religion and Human Rights Research Program, under which this current research is run, was issued by the Julius-Maximilian University of Wurzburg and is available upon request.

The instruments used in this study are described in detail in the following section. After the data were collected, they were processed and analysed with the help of PASW Statistics, version 18.

\subsection{Conceptualization and Operalization}

To explore the way in which religiosity influences individual values, support for human dignity and support for civil, judicial, political, and socioeconomic rights among Romanian high school students, three main hypotheses were formulated:

Hypothesis 1 (H1). Religiosity positively influences individual values (self-direction, security, benevolence, conformity, universalism, and traditionalism).

Hypothesis 2 (H2). Religiosity positively influences support for human dignity.

Hypothesis 3 (H3). Religiosity positively influences support for human rights.

In order to test the hypotheses, the conceptual model presented in Figure 1 was used, taking into account three groups of variables: religiosity (independent), individual values and human dignity (both independent and control variables), civil, judicial, political and socioeconomic rights (dependent), and gender, religious denomination, religious socialization and empathy (background variables). In what follows, each of the concepts included in Figure 1 will be described in some detail. For all the instruments based on scales, a Cronbach alpha of minimum 0.60 was considered acceptable.

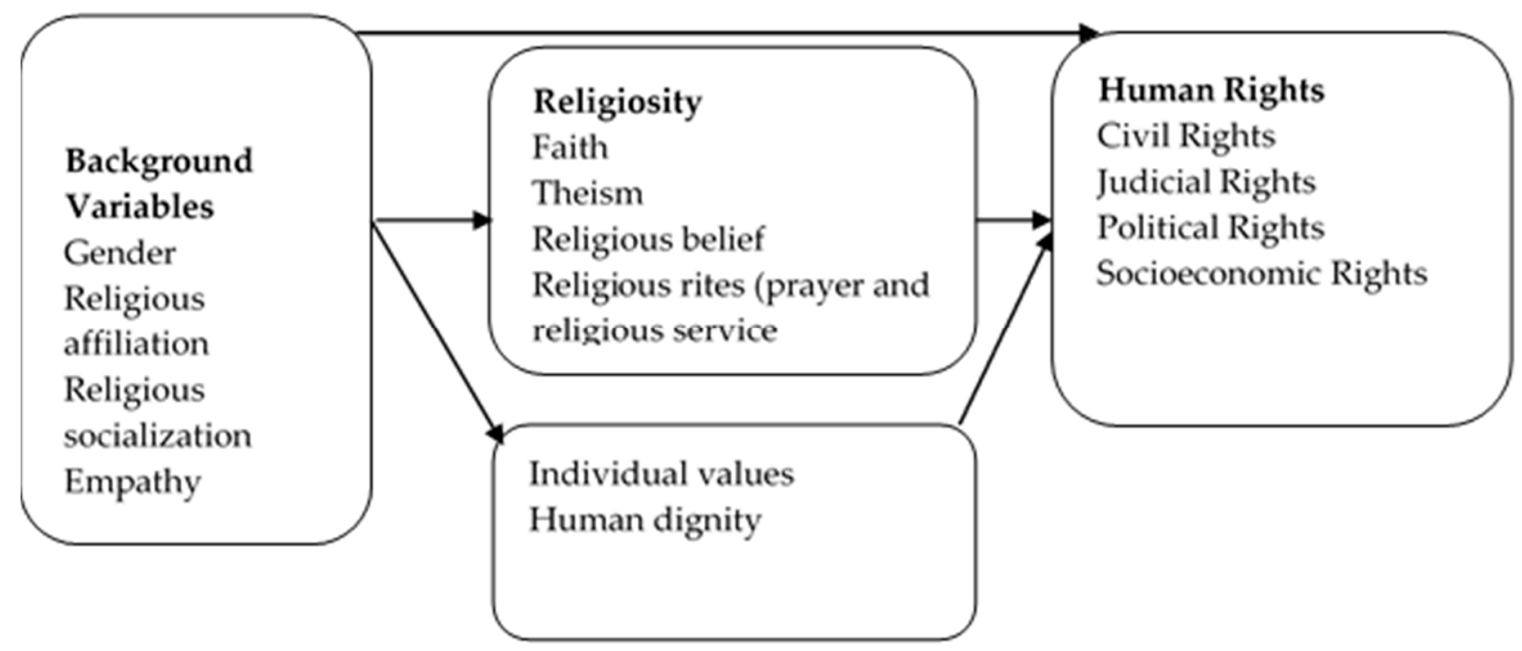

Figure 1. Conceptual model for research study.

\subsubsection{Religiosity}

Religiosity in the current study was defined and assessed through the following components: faith, theism, religious belief, and religious rites (frequency of prayer and religious service attendance).

Faith was measured with the help of two items (Kass et al. 1991): "People say that their faith gives them a certainty in life that they otherwise would not have" and "People say that their faith has often helped them not to lose courage in particular situations". Respondents were asked to indicate whether 
they have experienced the above statements on a scale from 1 to 5 , where 1 is "never had" and 5 is "very often had". The Cronbach alpha is 0.75 .

Theism is measured with the help of two dimensions from a larger instrument used in the survey to investigate agreement with various concepts about God. The two items are: "I believe God is the foundation of everything that exists" and "I believe that God is the very basis of everything that lives". The answers were recorded on a scale from 1 to 5 , where 1 is "I totally disagree" and 5 "I fully agree". The Cronbach alpha for the aggregated measure is 0.90 .

Religious belief is measured with the help of three items: "How often do you think about religious issues", "To what extent do you believe that God or something divine exists?" and "What is your position on the statement: 'My religion or worldview has a great influence on my daily life'? Respondents were asked to indicate their level of agreement with the above statements on a scale from 1 to 5 , where 1 is "never" and 5 is "very often". The Cronbach alpha for the aggregated measure is 0.69 .

As far as religious rites are concerned, two aspects are taken into consideration: the frequency of prayer ("How often do you pray?") and religious service attendance ("How often do you take part in religious services at a church or mosque or another place?"). In both cases, respondents were asked to indicate whether they agree with the above statements on a scale from 1 to 5 , where 1 is "never" and 5 is "very often".

\subsubsection{Individual Values and Human Dignity}

In the present study, six individual values and human dignity (merit, moral and intrinsic human dignity) act as dependent variables, to investigate the influence of religiosity on support for individual values and human dignity. Secondly, these were employed as control variables, to investigate their potential influence on support for human rights. For the individual value system, Schwartz and Sagiv's (1995) concepts were included. On a scale from 1 to 6 where 1 is "is not like me" and 6 is "is like me", participants were asked to indicate their level of agreement towards the following: self-direction, security, benevolence, conformity, universalism and tradition. To measure attitudes towards human dignity, Nordenfelt's (2004) notions of dignity were employed as follows: the human dignity of merit ("The value of a person depends on the appreciation given to him or her by others"); the human dignity of moral stature ("The honour to be given to a person depends on his moral behaviour"); and intrinsic human dignity ("Each human being should be recognized just because he is a human being, irrespective of credit or moral behaviour"). The respondents' level of agreement was recorded on a scale from 1 to 5 , where 1 is "I totally disagree" and 5 is "I fully agree".

\subsubsection{Human Rights}

Support for human rights is included as a dependent variable in this study. The following human rights are included: civil, judicial, political, and socioeconomic rights. The answers were measured on a scale from 1 to 5 , where 1 is "I totally disagree" and 5 is "I fully agree".

Civil rights are measured with the help of 16 items and cover the following dimensions: privacy, freedom of speech, of assembly, freedom of and to practice religion, protection from discrimination and prohibition of inhumane treatment. One sample item is "Our laws should protect people's right to live by any moral values they choose". Cronbach alpha is 0.80 .

Judicial rights are measured with the help of 8 items, covering the following dimensions: right to protection from torture, right to remain silent, right to a search warrant to be shown and right to legal aid. One sample item is "Mass murderers should be guaranteed access to a lawyer". Cronbach alpha is 0.67 .

Political rights are measured with the help of 6 items, which cover issues such as active and passive right to vote, right of protest and right of refugees. One sample item is "The government should guarantee political refugees freedom to travel". Cronbach alpha is 0.66 .

The final category of human rights, socioeconomic rights, is measured with the help of 12 items covering six dimensions: state's obligation regarding the right to work, the right to social security, 
living wages, rest and leisure, the right of children, and education. One sample item is "Everyone should have the right to equal pay for equal work". Cronbach alpha is 0.88 .

\subsubsection{Background Variables}

Due to their potential influence on the dependent variables, as also indicated by previous research (Rogobete and Vitelar 2020), several background variables that relate to personal characteristics (gender), religious affiliation, religious socialisation, and the psychological dimension of empathy were included in the current study. Religious affiliation is measured by asking the respondent to identify themselves with one of the 12 affiliations listed in the survey. Religious socialisation is measured with the help of the following item: "How would you describe your parents' (or foster-/stepparents') and best friends' belief and faith in God or a higher reality?" Empathy is measured with the help of items from an instrument developed by Davis $(1980,1983)$. The four items are measured on a scale from 1 to 5 , where 1 is "strongly disagree" and 5 is "strongly agree". One sample item is "I often have tender, concerned feelings for people less fortunate than $\mathrm{me}^{\prime}$. Cronbach alpha for the present sample is 0.70 .

\section{Results}

The frequencies, means and standard deviations of the variables used in this research can be consulted in the supporting information as Supplementary Materials Tables S1-S14.

Before engaging in hierarchical multiple regression analysis to test the proposed hypotheses, correlation analysis was employed to investigate whether there are significant correlations between the independent, dependent and background variables in the conceptual model. Table 1 presents the correlations among the background, independent and dependent variables. The results indicate multiple weak correlations. In what follows, details are given on the moderate and strong correlations. Positive moderate relationships were found between universalism and best friend's belief and faith $(r=0.33, p<0.001)$, as well as traditionalism and father's belief and faith $(r=0.32, p<0.001)$, best friend's belief and faith $(r=0.37, p<0.001)$, theism $(r=46, p<0.001)$, religious belief $(r=0.42, p<0.001)$, frequency of prayer $(r=0.44, p<0.001)$ and religious service attendance $(\mathrm{r}=0.36, p<0.001)$. A strong correlation was also found between benevolence and empathy $(r=0.53, p<0.001)$. Only significant correlations were included in regression analyses. In addition, dummy coding was used for gender and religious affiliation. For gender, the regression model only includes one dummy variable (female). 
Table 1. Correlations (Pearson's r) between faith, theism, religious belief, prayer, religious service attendance, individual values, human dignity, and background variables.

\begin{tabular}{|c|c|c|c|c|c|c|c|c|c|c|c|}
\hline Variable & Mean & SD & Self-Direction & Security & Bene-Volence & Conformity & Universalism & Tradition & $\begin{array}{c}\text { Merit } \\
\text { Dignity }\end{array}$ & $\begin{array}{c}\text { Moral } \\
\text { Dignity }\end{array}$ & $\begin{array}{c}\text { Intrinsic } \\
\text { Dignity }\end{array}$ \\
\hline \multicolumn{12}{|l|}{ Background characteristics } \\
\hline Gender & 1.49 & 0.50 & $-0.08 *$ & -0.11 ** & $-0.21 * *$ & -0.12 ** & -0.04 & -0.05 & 0.07 & $-0.15^{* *}$ & $-0.08 *$ \\
\hline Father's belief \& faith & 4.39 & 1.09 & $0.12 *$ & $0.11 *$ & $0.21^{* *}$ & $0.17^{* *}$ & 0.09 & $0.32 * *$ & 0.04 & $0.15^{* *}$ & -0.00 \\
\hline Mother's belief \& faith & 4.58 & 0.93 & $0.11 *$ & 0.11 * & $0.18^{* *}$ & 0.07 & $0.12 * *$ & $0.19 * *$ & -0.06 & $0.20^{* *}$ & -0.02 \\
\hline Best friend's belief \& faith & 4.13 & 1.23 & -0.09 & 0.09 * & $0.21^{* *}$ & 0.09 & 0.08 & $0.37^{* *}$ & 0.00 & $0.09 *$ & 0.11 * \\
\hline Empathy & 3.6 & 0.73 & $0.23^{* *}$ & $0.19 * *$ & $0.53^{* *}$ & $0.15^{* *}$ & $0.33^{* *}$ & $0.22 * *$ & -0.01 & $0.22^{* *}$ & 0.01 \\
\hline Christian Orthodox & 0.72 & 0.44 & -0.12 ** & $0.08 *$ & 0.03 & $0.15^{* *}$ & 0.09 & $0.22 * *$ & 0.04 & 0.13 ** & 0.03 \\
\hline Christian & 0.02 & 0.12 & -0.03 & 0.03 & 0.01 & -0.02 & 0.01 & 0.02 & -0.00 & -0.02 & -0.05 \\
\hline \multicolumn{12}{|l|}{ Independent variables } \\
\hline Faith & 3.36 & 1.07 & $0.10 *$ & 0.09 * & $0.15^{* *}$ & 0.03 & $0.12 * *$ & $0.17^{* *}$ & -0.07 & $0.12^{* *}$ & -0.01 \\
\hline Theism & 3.36 & 1.32 & 0.04 & $0.14^{* *}$ & $0.24^{* *}$ & $0.19 * *$ & $0.08 *$ & $0.46^{* *}$ & 0.05 & $0.13 * *$ & $0.15^{* *}$ \\
\hline Religious belief & 3.24 & 0.93 & $0.12 * *$ & $0.17^{* *}$ & $0.27^{* *}$ & $0.19^{* *}$ & $0.18^{* *}$ & $0.42 * *$ & -0.01 & $0.15^{* *}$ & 0.04 \\
\hline Prayer & 4.90 & 2.47 & -0.03 & $0.13^{* *}$ & $0.21 * *$ & $0.22 * *$ & 0.06 & $0.44^{* *}$ & 0.05 & 0.06 & $0.11^{* *}$ \\
\hline Religious service attendance & 2.93 & 1.35 & -0.02 & 0.08 * & $0.18^{* *}$ & $0.13^{* *}$ & 0.04 & $0.36^{* *}$ & -0.01 & 0.02 & $0.15^{* *}$ \\
\hline
\end{tabular}




\subsection{Hypotheses Testing}

Hierarchical multiple regression was employed to analyse the ability of the independent variables to predict support for the dependent variables. The relevant background and/or control variables were entered in step one, while the independent variables were entered in step two.

Hypothesis 1 (H1). Religiosity positively influences individual values (self-direction, security, benevolence, conformity, universalism, and traditionalism).

\subsubsection{Religiosity and Self-Direction}

The background variables accounted for $8 \%$ of the variance in the dependent variable. Once the independent variables were added, the model continued to account for $8 \%$ of the variance in self-direction $\left(R^{2}=0.08, F(7381)=4.63, p<0.001\right)$. The independent variables explained an additional variance of under $1 \%\left(\Delta R^{2}=0.00, \Delta F(2381)=0.48, p=0.616\right)$, which is not statistically significant. As seen in Table 2, the coefficients in the final model show that only empathy and Christian Orthodox affiliation are significant predictors of self-direction. While empathy is a positive predictor of self-direction, being a Christian Orthodox is negatively associated with self-direction. Thus, in the case of self-direction, only two background variables remain significant predictors.

Table 2. Regression analyses for self-direction with weights $(\beta)$ for each variable and total explained variance $\left(R^{2}\right.$ and adjusted $\left.R^{2}\right)$.

\begin{tabular}{lc}
\hline \multicolumn{1}{c}{ Variables } & Self-Direction \\
\hline Background characteristics & \\
Gender (Female) & 0.044 \\
Father's belief \& faith & 0.071 \\
Mother's belief \& faith & 0.065 \\
Empathy & $0.198^{* *}$ \\
Christian Orthodox & $-0.144^{*}$ \\
Independent Variables & 0.049 \\
Faith & -0.032 \\
Religious belief & 0.079 \\
\hline \multicolumn{2}{c}{ Adj. $R^{2}$} \\
\hline
\end{tabular}

\subsubsection{Religiosity and Security}

In the first model, the background variables accounted for $5 \%$ of the variance in the dependent variable $(p<0.05)$. Once the independent variables were added, the model accounted for $6 \%$ of the variance in security $\left(R^{2}=0.06, F(11,321)=1.89, p<0.05\right)$. The independent variables explained an additional $1 \%$ of the variance $\left(\Delta R^{2}=0.01, \Delta F(5321)=0.95, p=0.448\right)$, which is not statistically significant. As seen in Table 3, none of the study variables remain significant predictors of security. 
Table 3. Regression analysis for security with weights $(\beta)$ for each variable and total explained variance $\left(R^{2}\right.$ and adjusted $\left.R^{2}\right)$.

\begin{tabular}{lc}
\hline \multicolumn{1}{c}{ Variables } & Security \\
\hline Background characteristics & \\
Gender (Female) & 0.061 \\
Father's belief \& faith & 0.008 \\
Mother's belief \& faith & 0.121 \\
Best friend's belief \& faith & 0.075 \\
Empathy & 0.106 \\
Christian Orthodox & 0.063 \\
Independent Variables & 0.058 \\
Faith & 0.090 \\
Religious belief & -0.069 \\
Theism & -0.080 \\
Prayer & -0.026 \\
Religious service attendance & 0.061 \\
\multicolumn{2}{r}{$R^{2}$} \\
Adj. $R^{2}$ & 0.029 \\
\hline
\end{tabular}

\subsubsection{Religiosity and Benevolence}

In the first model, the background variables accounted for $29 \%$ of the variance in the dependent variable $(p<0.001)$. Once the independent variables were added, the model accounted for $30 \%$ of the variance in benevolence $\left(R^{2}=0.30, F(10,322)=13.78, p<0.001\right)$. The independent variables explained under $1 \%$ of the additional variance $\left(\Delta R^{2}=0.00, \Delta F(5322)=0.81, p=0.541\right)$. As seen in Table 4 , only empathy remains a positive predictor of benevolence. In addition, female respondents are positively associated with benevolence.

Table 4. Regression analysis for benevolence with weights $(\beta)$ for each variable and total explained variance $\left(R^{2}\right.$ and adjusted $\left.R^{2}\right)$.

\begin{tabular}{lc}
\hline \multicolumn{1}{c}{ Variables } & Benevolence \\
\hline Background characteristics & \\
Gender (Female) & $0.121^{*}$ \\
Father's belief \& faith & 0.080 \\
Mother's belief \& faith & 0.102 \\
Best friend's belief \& faith & 0.088 \\
Empathy & $0.445^{* *}$ \\
Independent Variables & 0.038 \\
Faith & -0.081 \\
Religious belief & 0.102 \\
Theism & -0.095 \\
Prayer & -0.008 \\
Religious service attendance & 0.300 \\
\multicolumn{2}{c}{$R^{2}$} \\
\multicolumn{2}{c}{ Adj. $R^{2}$} \\
\hline \multicolumn{2}{c}{0.278} \\
\hline
\end{tabular}

\subsubsection{Religiosity and Conformity}

The background variables accounted for $6 \%$ of the variance in the dependent variable $(p<0.001)$. Once the independent variables were added, the model accounted for $8 \%$ of the variance in conformity $\left(R^{2}=0.08, F(8421)=4.71, p<0.001\right)$. The independent variables explained under $1 \%$ of the additional variance $\left(\Delta R^{2}=0.03, \Delta F(4421)=3.08, p<0.001\right)$. As seen in Table 5, religious belief and Christian 
Orthodox denomination remain significant positive predictors of conformity. However, the overall model explains little of the variance in support for conformity.

Table 5. Regression analysis for conformity with weights $(\beta)$ for each variable and total explained variance $\left(R^{2}\right.$ and adjusted $\left.R^{2}\right)$.

\begin{tabular}{lc}
\hline \multicolumn{1}{c}{ Variables } & Conformity \\
\hline Background characteristics & \\
Gender (Female) & 0.042 \\
Father's belief \& faith & 0.063 \\
Christian Orthodox & $0.123^{*}$ \\
Empathy & 0.038 \\
Independent Variables & -0.108 \\
Theism & $0.175^{*}$ \\
Religious belief & 0.107 \\
Prayer & -0.003 \\
Religious service attendance & 0.082 \\
\hline \multicolumn{2}{c}{$R^{2}$} \\
\multicolumn{2}{c}{ Adj. $R^{2}$} \\
\hline \multicolumn{2}{c}{0.065} \\
\hline
\end{tabular}

\subsubsection{Religiosity and Universalism}

The background variables accounted for $12 \%$ of the variance in the dependent variable $(p<0.001)$. Once the independent variables were added, the model accounted for $14 \%$ of the variance in universalism $\left(R^{2}=0.14, F(5453)=14.95, p<0.001\right)$. The independent variables explained under $1 \%$ of the additional variance $\left(\Delta R^{2}=0.02, \Delta F(3453)=3.54, p<0.05\right)$. As seen in Table 6, empathy, religious belief, and theism remain significant predictors of universalism. It is noteworthy that there is a negative relationship between theism and universalism, meaning that the less the respondents believe that God is the foundation of everything that exists and lives, the greater the support for universalism.

Table 6. Regression analysis for universalism with weights $(\beta)$ for each variable and total explained variance $\left(R^{2}\right.$ and adjusted $\left.R^{2}\right)$.

\begin{tabular}{lc}
\hline \multicolumn{1}{c}{ Variables } & Universalism \\
\hline Background characteristics \\
Father's belief \& faith & 0.058 \\
Empathy & $0.321^{* *}$ \\
Independent Variables & $-0.154^{*}$ \\
Theism & $0.136^{*}$ \\
Religious belief & 0.078 \\
Faith & 0.142 \\
\hline \multicolumn{2}{c}{ Adj. $R^{2}$} \\
\hline \multicolumn{2}{c}{0.132} \\
\hline \multicolumn{2}{c}{ Note, ${ }^{*} p<0.05 ;{ }^{* *} p<0.01}$.
\end{tabular}

\subsubsection{Religiosity and Traditionalism}

The background variables accounted for $21 \%$ of the variance in the dependent variable $(p<0.001)$. Once the independent variables were added, the model accounted for $36 \%$ of the variance in traditionalism $\left(R^{2}=0.36, F(10,322)=18.38, p<0.001\right)$. The independent variables explained an additional $14 \%$ of the variance $\left(\Delta R^{2}=0.14, \Delta F(5322)=15.03, p<0.001\right)$. As seen in Table 7 , theism remains the only significant predictor of traditionalism. 
Table 7. Regression analysis for traditionalism with weights $(\beta)$ for each variable and total explained variance $\left(R^{2}\right.$ and adjusted $\left.R^{2}\right)$.

\begin{tabular}{lc}
\hline \multicolumn{1}{c}{ Variables } & Tradition \\
\hline Background characteristics & \\
Father's belief \& faith & 0.059 \\
Mother's belief \& faith & -0.036 \\
Best friend's belief \& faith & 0.095 \\
Empathy & 0.044 \\
Christian Orthodox & 0.085 \\
Independent Variables & $0.315^{* *}$ \\
Theism & 0.066 \\
Faith & 0.038 \\
Religious belief & 0.083 \\
Prayer & 0.093 \\
Religious service attendance & 0.363 \\
\multicolumn{2}{c}{$R^{2}$} \\
\multicolumn{2}{c}{ Adj. $R^{2}$} \\
\hline
\end{tabular}

The first hypothesis is only partially supported since only some of the dimensions of religiosity were found to positively influence individual values. As such, religious belief positively influences conformity and universalism, while theism positively influences traditionalism. At the same time, some of the background variables were found to significantly influence self-direction, benevolence (gender and empathy), conformity (Christian Orthodox) and universalism (empathy). However, overall, much of the variance remains unexplained in the case of self-direction, security, and conformity.

Hypothesis 2 (H2). Religiosity positively influences support for human dignity.

As indicated in Table 1, there are no significant correlations between the background, independent variables, and the merit view of human dignity. As far as the moral and intrinsic views on human dignity are concerned, the results of correlation analysis reveal several weak significant relationships, which were introduced in the regression analysis.

\subsubsection{Religiosity and Moral Dignity}

The background variables accounted for $10 \%$ of the variance in the dependent variable $(p<0.001)$. Once the independent variables were added, the model accounted for $13 \%$ of the variance in the moral dimension of human dignity $\left(R^{2}=0.13, F(9344)=5.49, p<0.001\right)$. The independent variables explained an additional $3 \%$ of the variance $\left(\Delta R^{2}=0.03, \Delta F(3344)=3.35, p<0.05\right)$. As seen in Table 8 , empathy and faith remain significant positive predictors of moral dignity.

Table 8. Regression analysis for moral dignity with weights $(\beta)$ for each variable and total explained variance $\left(R^{2}\right.$ and adjusted $\left.R^{2}\right)$.

\begin{tabular}{lc}
\hline \multicolumn{1}{c}{ Variables } & Moral Dignity \\
\hline Background characteristics & \\
Gender (Female) & 0.087 \\
Father's belief \& faith & 0.039 \\
Mother's belief \& faith & 0.118 \\
Best friend's belief \& faith & 0.031 \\
Empathy & $0.147^{*}$ \\
Christian Orthodox & 0.104 \\
\hline
\end{tabular}


Table 8. Cont.

\begin{tabular}{lcc}
\hline \multicolumn{1}{c}{ Variables } & Moral Dignity \\
$\begin{array}{l}\text { Independent Variables } \\
\text { Theism }\end{array}$ & -0.081 \\
Faith & & $0.138^{*}$ \\
Religious belief & & 0.084 \\
\hline & $R^{2}$ & 0.126 \\
& Adj. $R^{2}$ & 0.103 \\
\hline
\end{tabular}

Note, ${ }^{*} p<0.05$

\subsubsection{Religiosity and Intrinsic Human Dignity}

The background variables accounted for $2 \%$ of the variance in the dependent variable $(p<0.05)$. Once the independent variables were added, the model accounted for $4 \%$ of the variance in intrinsic human dignity $\left(R^{2}=0.04, F(5441)=3.77, p<0.05\right)$. The independent variables explained an additional $2 \%$ of the variance $\left(\Delta R^{2}=0.02 \Delta F(3441)=2.79, p<0.05\right)$. As seen in Table 9, none of the variable included are significant predictors.

Table 9. Regression analysis for intrinsic human dignity with weights $(\beta)$ for each variable and total explained variance $\left(R^{2}\right.$ and adjusted $\left.R^{2}\right)$.

\begin{tabular}{lc}
\hline \multicolumn{1}{c}{ Variables } & Intrinsic Human Dignity \\
\hline Background characteristics & \\
Gender (Female) & 0.081 \\
Best friend's belief \& faith & 0.047 \\
Independent Variables & \\
Theism & 0.145 \\
Prayer & -0.110 \\
Religious service attendance & 0.102 \\
\hline & 0.041 \\
$R^{2}$ & 0.030 \\
\hline
\end{tabular}

Following the regression analyses for the two components of human dignity, the results indicate only partial support for the hypothesis. While the findings reveal that faith is a positive predictor of moral dignity, none of the included independent variables remain significant predictors of intrinsic human dignity and much of the variance in support for this component of human dignity remains unexplained.

Hypothesis 3 (H3). Religiosity positively influences support for human rights.

Similarly to the testing of the first two hypotheses, before engaging in hierarchical multiple regression analysis to test the final hypothesis (H3), correlation analysis was employed to investigate whether there are significant correlations between human rights, independent and background variables.

As seen in Table 10, correlation analysis revealed multiple weak and moderate significant positive and negative relationships among the study variables. In what follows, details are presented on the moderate correlations. Positive moderate relationships were found between civil rights and self-direction $(r=0.42, p<0.001)$ and benevolence $(r=0.34, p<0.001)$. Positive moderate relationships were also found between socioeconomic rights and empathy $(r=0.37, p<0.001)$, self-direction $(r=0.36$, $p<0.001)$, security $(r=0.30, p<0.001)$ and benevolence $(r=0.35, p<0.001)$. All of the significant correlations were further introduced in multiple regression analyses. 
Table 10. Correlations (Pearson's $r$ ) between human rights, independent and control variables.

\begin{tabular}{|c|c|c|c|c|c|c|}
\hline Variable & Mean & SD & Civil Rights & Judicial Rights & Political Rights & Socioeconomic Rights \\
\hline \multicolumn{7}{|l|}{ Background characteristics } \\
\hline Gender & 1.49 & 0.50 & $-0.20^{* *}$ & 0.01 & -0.05 & $-0.22 * *$ \\
\hline Father's belief \& faith & 4.39 & 1.09 & 0.06 & $-0.15^{* *}$ & -0.04 & $0.17^{* *}$ \\
\hline Mother's belief \& faith & 4.58 & 0.93 & $0.14^{* *}$ & -0.06 & 0.01 & $0.16^{* *}$ \\
\hline Best friend's belief \& faith & 4.13 & 1.23 & 0.03 & $-0.12 *$ & -0.03 & $0.15^{* *}$ \\
\hline Empathy & 3.6 & 0.73 & $0.29 * *$ & -0.05 & $0.12 *$ & $0.37^{* *}$ \\
\hline Christian Orthodox & 0.72 & 0.44 & -0.01 & $-0.09 *$ & -0.04 & 0.06 \\
\hline Christian & 0.02 & 0.12 & -0.07 & 0.06 & -0.03 & 0.04 \\
\hline \multicolumn{7}{|l|}{ Independent variables } \\
\hline Faith & 3.36 & 1.07 & $0.13^{* *}$ & 0.05 & -0.01 & $0.14^{* *}$ \\
\hline Theism & 3.36 & 1.32 & 0.05 & $-0.10^{* *}$ & 0.01 & $0.23^{* *}$ \\
\hline Religious belief & 3.24 & 0.93 & $0.15^{* *}$ & -0.05 & 0.06 & $0.27 * *$ \\
\hline Prayer & 4.90 & 2.47 & 0.01 & -0.07 & -0.04 & $0.19 * *$ \\
\hline Religious service attendance & 2.93 & 1.35 & -0.04 & -0.07 & -0.05 & 00.70 \\
\hline Self-Direction & 4.71 & 1.38 & $0.42 * *$ & 0.04 & $0.16^{* *}$ & $0.36^{* *}$ \\
\hline Security & 4.50 & 1.41 & $0.21^{* *}$ & -0.00 & 0.01 & $0.30^{* *}$ \\
\hline Benevolence & 4.62 & 1.27 & $0.34 * *$ & -0.06 & $0.08 *$ & $0.35^{* *}$ \\
\hline Conformity & 3.96 & 1.48 & $0.11^{* *}$ & -0.05 & $0.08 *$ & $0.17^{* *}$ \\
\hline Universalism & 4.47 & 1.32 & $0.28^{* *}$ & 0.03 & $0.11 *$ & $0.29 * *$ \\
\hline Tradition & 3.56 & 1.55 & 0.01 & $-0.08 *$ & -0.07 & $0.13^{* *}$ \\
\hline Merit dignity & 2.46 & 1.17 & $-0.11^{* *}$ & -0.07 & -0.01 & -0.06 \\
\hline Moral dignity & 3.79 & 0.94 & $0.25^{* *}$ & -0.02 & 0.06 & $0.28 * *$ \\
\hline Intrinsic dignity & 2.91 & 1.22 & -0.01 & 0.08 & 0.05 & 0.00 \\
\hline
\end{tabular}

Note, ${ }^{*} p<0.05 ; * * p<0.01$ 


\subsubsection{Religiosity and Civil Rights}

The background variables, self-direction, benevolence, conformity, and universalism accounted for $30 \%$ of the variance in the dependent variable $(p<0.001)$. Once the independent variables were added, the model accounted for $31 \%$ of the variance in support for civil rights $\left(R^{2}=0.31, F(12,429)=15.87\right.$, $p<0.001)$. The independent variables explained under $1 \%$ of the additional variance in civil rights $\left(\Delta R^{2}=0.00 \Delta F(2429)=1.80, p=0.17\right)$. As seen in Table 11, only self-direction and moral dignity remain significant positive predictors of support for civil rights.

Table 11. Regression analysis for civil rights with weights $(\beta)$ for each variable and total explained variance $\left(R^{2}\right.$ and adjusted $\left.R^{2}\right)$.

\begin{tabular}{lc}
\hline \multicolumn{1}{c}{ Variables } & Civil Rights \\
\hline Background characteristics & \\
Gender (Female) & 0.087 \\
Mother's belief \& faith & 0.029 \\
Empathy & 0.073 \\
Values & \\
Self-Direction & $0.337^{* *}$ \\
Security & 0.029 \\
Benevolence & 0.101 \\
Conformity & 0.021 \\
Universalism & 0.036 \\
Merit Dignity & -0.052 \\
Moral Dignity & $0.119 *$ \\
Independent Variables & \\
Faith & 0.079 \\
Religious belief & 0.000 \\
\hline & 0.307 \\
\hline & $R^{2}$ \\
\hline
\end{tabular}

Note, ${ }^{*} p<0.05 ; * * 0.01$.

\subsubsection{Religiosity and Judicial Rights}

The background variables accounted for $4 \%$ of the variance in the dependent variable $(p<0.001)$. Once the independent variable theism was added, the model accounted for $5 \%$ of the variance in support for judicial rights $\left(R^{2}=0.05, F(4393)=4.99, p<0.05\right)$. The independent variable explained under $1 \%$ of the additional variance in support for judicial rights $\left(\Delta R^{2}=0.00 \Delta F(1393)=1.64, p=0.20\right)$. As Table 12 indicates, none of the variables included in the model remain significant predictors and much of the variance in support for judicial rights remains unexplained.

Table 12. Regression analysis for judicial rights with weights $(\beta)$ for each variable and total explained variance $\left(R^{2}\right.$ and adjusted $\left.R^{2}\right)$.

\begin{tabular}{|c|c|}
\hline Variables & Judicial Rights \\
\hline \multicolumn{2}{|l|}{ Background characteristics } \\
\hline Father's belief \& faith & -0.105 \\
\hline Best friend's belief \& faith & -0.040 \\
\hline Christian Orthodox & -0.081 \\
\hline \multicolumn{2}{|l|}{ Independent Variables } \\
\hline Theism & -0.077 \\
\hline$R^{2}$ & 0.048 \\
\hline Adj. $R^{2}$ & 0.039 \\
\hline
\end{tabular}




\subsubsection{Religiosity and Political Rights}

As seen in Table 10 above, no significant correlations were found among the components of religiosity and political rights. Some positive relationships were found between political rights and empathy, self-direction, benevolence, conformity, and universalism. However, these variables accounted for only $4 \%$ of the variance in support for political rights $\left(R^{2}=0.04, F(5655)=4.81, p<0.001\right)$, with self-direction being the only significant predictor in the model (Table 13). As such, much of the variance in support for political rights remains unexplained.

Table 13. Regression analysis for political rights with weights $(\beta)$ for each variable and total explained variance $\left(R^{2}\right.$ and adjusted $\left.R^{2}\right)$.

\begin{tabular}{cc}
\hline Variables & Political Rights \\
\hline $\begin{array}{c}\text { Background characteristics } \\
\text { Empathy }\end{array}$ \\
$\begin{array}{c}\text { Independent Variables } \\
\text { Self-Direction }\end{array}$ \\
Benevolence & 0.081 \\
Conformity & -0.03 \\
Universalism & 0.05 \\
\multicolumn{2}{c}{ Adj. $R^{2}$} \\
\hline \multicolumn{2}{c}{$R^{2}$} \\
Note, ${ }^{*} p<0.05$.
\end{tabular}

\subsubsection{Religiosity and Socioeconomic Rights}

The background variables, self-direction, security, benevolence, conformity, universalism, and moral dignity accounted for $25 \%$ of the variance in the dependent variable $(p<0.001)$. Once the independent variables (faith, theism, religious belief, and prayer) were added, the model accounted for $26 \%$ of the variance in support for socioeconomic rights $\left(R^{2}=0.26, F(15,322)=7.65, p<0.001\right)$. The independent variables explained under $1 \%$ of the additional variance in support for socioeconomic rights $\left(\Delta R^{2}=0.02 \Delta F(4322)=1.88, p=0.11\right)$. As seen in Table 14, self-direction, moral dignity, and religious belief remain significant predictors of socioeconomic rights.

Table 14. Regression analysis for socioeconomic rights with weights $(\beta)$ for each variable and total explained variance $\left(R^{2}\right.$ and adjusted $\left.R^{2}\right)$.

\begin{tabular}{lc}
\hline \multicolumn{1}{c}{ Variables } & Socioeconomic Rights \\
\hline Background characteristics & \\
Gender (Female) & 0.064 \\
Father's belief \& faith & -0.020 \\
Mother's belief \& faith & -0.009 \\
Best friend's belief \& faith & 0.055 \\
Empathy & 0.065 \\
Values & $0.227^{* *}$ \\
Self-Direction & 0.088 \\
Security & 0.062 \\
Benevolence & 0.025 \\
Conformity & 0.071 \\
Universalism & $0.151^{*}$ \\
Moral Dignity &
\end{tabular}


Table 14. Cont.

\begin{tabular}{|c|c|}
\hline Variables & Socioeconomic Rights \\
\hline \multicolumn{2}{|l|}{ Independent Variables } \\
\hline Theism & -0.089 \\
\hline Faith & 0.018 \\
\hline Religious belief & $0.153 *$ \\
\hline \multirow[t]{3}{*}{ Prayer } & 0.065 \\
\hline & 0.263 \\
\hline & 0.228 \\
\hline
\end{tabular}

Note, ${ }^{*} p<0.05 ;{ }^{* *} p<0.01$.

Overall, the third hypothesis is only partially supported, in the sense that one element of religiosity, namely religious belief, was found to positively influence support for only one category of human rights, namely socioeconomic rights. On the other hand, it is important to note that some individual values and the moral view of human dignity were found to significantly contribute to the variance in support for human rights. As such, self-direction is a positive predictor of support for civil, political, and socioeconomic rights, while moral dignity is a positive predictor of civil and socioeconomic rights.

\section{Discussion}

\subsection{Religiosity and Individual Values for Development}

The first hypothesis stating that religiosity positively influences individual values is only partially supported. As part of religiosity, religious belief was found to positively influence conformity and universalism. In other words, religious belief, understood in this study as a personal identity provider, dealing with metaphysical inner issues (such as thinking about the existence of God, or considering religion to have a great influence on one's daily life), has a positive predictive value for conformity-defined as living a moral life and having a behaviour accepted by the generally established social norms. In addition, religious belief positively influences universalism, defined as an inclination to live a life that cares for nature and shows concern for the environment. Both of these findings are supported by earlier studies and theories, stating that religion, as a metaphysical reality, can be a resource for building a moral sense of self, which, in turn, can facilitate the development of attitudes and behaviours that promote sustainable development concerns (Deneulin and Bano 2009; Narayanan 2013; Ives and Kidwell 2019).

Another dimension of religiosity, theism, is the only positive predictor for traditionalism and a negative predictor for universalism. This finding is in accordance with the earlier meta-analysis of Saroglou et al. (2004), which also shows that religion positively influences values that promote conservation of social and individual order, along with limited support for self-transcendent values (i.e., universalism). Theism was understood as a belief in the centrality of the existence of God as the foundation of everything that exists and lives. Individuals holding theism as an important aspect of their religiosity seem to place an important role on following the customs handed down by ones' religion or his/her family. This is much in line with the adult population of Romania, in which $84 \%$ of the total population claim that religion is very important in their family, the Christian religion being preserved from childhood to adulthood (Romania Credincioasa 2015). At the same time, theism seems to predict lesser concern for nature and the environment. It may, therefore, lower the propensity for furthering a sustainable agenda in the field of environmental strategies and sustainable development, and thus rendering aspects of religion irrelevant (Ekardt 2020).

Empathy, as a background variable, was found to significantly influence self-direction, benevolence and universalism. These findings emphasize a coherent sense of self, whose ability to feel for others is reflected in his/her creativity, originality (self-direction), inclination towards getting involved in acts of kindness to others and the environment (benevolence and universalism). 
Finally, belonging to the Christian Orthodox denomination is another background variable found to have a positive influence on conformity, and a negative influence on self-direction. Young people identifying themselves as belonging to the majority religious group in Romania, where $87 \%$ of Romanians identify themselves as Christian Orthodox (Romania Credincioasa 2015), seem to value the need to match attitudes and behaviour to the group norms and rules. They also appear to place less importance on creativity, originality and acting independently (self-direction). Such findings are also in accordance with the previously mentioned empirical meta-analysis (Saroglou et al. 2004), and in line with general attitudes of the Romanian population to value and preserve its religious tradition. A possible explanation for Romania could be found in existing studies that find the Romanian Orthodox Church to be an institution strongly oriented towards conservation and preservation of the tradition, and therefore often at odds with modernity and the modern self (Stan and Turcescu 2007). As argued elsewhere, the Romanian Orthodox Church might need to go through some change, in terms of connecting its liturgical and theological insights more with the life and the personal development of the modern believer (Rogobete 2004; Bates 2013). The Catholic Church, for instance, has recently taken significant steps in this direction, creatively addressing some highly relevant issues related to sustainable development (Christie et al. 2019).

\subsection{Religiosity and Human Dignity}

The second hypothesis predicted that religiosity positively influences support for human dignity. The empirical results proved it again partially true, as only faith is a positive predictor for the moral dimension of human dignity. Empathy, as a background variable, is another positive predictor. Looking at the distribution of the support given by participants in our study to the three different forms of human dignity assessed, what can be observed is the low support for intrinsic dignity, the strong support given to moral dignity and almost no support for dignity of merit. Dignity for the respondents does not seem to depend on how a person is appreciated by others, but rather that dignity is a result of moral behaviour. However, a non-contingent, unconditional respect for human dignity is at a low $32.7 \%$, compared to other consolidated democratic regimes of human rights. A similar study conducted in Germany has shown that the highest support was given to intrinsic human dignity, with $65 \%$ of students agreeing or fully agreeing that it is important (Ziebertz et al. 2018). Such shortcoming might be a reflection of a lack of civic education on this topic, revealing a systemic weakness of the formal educational system, particularly bearing in mind that participants attend some of the best academic high schools of Romania.

Returning to the second hypothesis, it is worth noting that the religious items and the background variables introduced did not correlate with the dignity of merit, showing strong correlations with moral dignity and some weak correlations with intrinsic dignity. The results of the regression analysis revealed that the included variables explained little of the variance in intrinsic dignity $(4 \%)$ and that there were no significant predictors. Faith is the only religious significant predictor of respect for moral dignity, alongside empathy. The absence of any religious predictor for support for intrinsic human dignity seems to show that not only formal education, but religious education too, tend to place higher value on moral performance, rather than the intrinsic value of the human being. However, the students who take faith as a strong metaphysical value that gives them ultimate certainty in life, and the courage to face difficult situations do tend to value human dignity more, even if through a moral lens. Hence, faith, an important aspect of the religious self, was found to have a positive role in affirming human dignity, a crucial concept bridging human rights and sustainable development (Deneulin and Bano 2009).

\subsection{Religiosity, Human Rights and Sustainable Development}

The third working hypothesis stating that religiosity positively influences support for human rights is only partially supported. While the included variables explained little of the variance in judicial and political rights, the model explained a significant amount of the variance in support for civil 
and socioeconomic rights. The results indicate that out of all religious items introduced in the model, religious belief is the only significant positive predictor of support for socioeconomic rights, out of a wide range of human rights investigated. Socioeconomic rights refer to the right to work, the right to decent healthcare, decent lifestyle for the unemployed, fair pay for work, protection of children, and the right to education. Such rights are directly or indirectly enshrined in almost all 17 SDGs of the UN Agenda 2030. Thus, finding that religious belief positively predicts support for such rights shows the positive role religiosity can play in the area of development, in accordance with a number of studies engaged with in this work (Deneulin and Bano 2009; Narayanan 2013; Gas-Aixendri and Albareda-Tiana 2019). Students embracing a religious belief system claim that faith and belief in God form an important part of their worldview, contributing both to who they are, and to what they do. A worldview integrating religious values, such as self-sacrifice, the "golden rule", or unconditional "caritas", may lead to higher levels of support for socioeconomic rights (Narayanan 2013). Both Narayanan (2013) and Deneulin and Bano (2009) highlight the importance of religious belief for furthering socioeconomic development, as rooted in the deep concerns some religious persons might have for "alleviation of human suffering" (Narayanan 2013, p. 136) through promoting social justice and equality.

When individual values and human dignity were introduced into the model as independent variables for human rights, results show that self-direction and respect for moral dignity were positive predictors of civil and socioeconomic rights, while self-direction was a positive predictor of the valuing of political rights as well. Self-direction remains the main predictor for a propensity to affirm the widest range of rights: political, civil, and socioeconomic. The subjects in this sample who are more inclined towards autonomy and creativity are also those who tend to manifest more interest in and support for almost all forms of human rights. Their support includes developmental rights, but it also goes beyond, into supporting rights related to individual freedom, right to life, privacy, religion, and so on. This finding is in line with Sen's view of the role human agency and freedom play in human rights (Sen 1982) and development (Sen 2000). Moreover, it shows that religiosity has a real but limited role to play in this model for assessing predictors for the valuing of human rights and sustainable development.

\section{Conclusions}

The current study, triggered by some apparently contradictory social and political facts, aimed to shed some light on the impact the high levels of religiosity have on values and attitudes conducive towards support for sustainable development in an important sector of the young generation of Romanian students. The findings show that some dimensions of religiosity (religious belief and theism) are positive predictors for universalism, a fundamental individual value that can be found at the foundation of almost any sustainable development behaviour. However, theism was also found to be a positive predictor for traditionalism and negative predictor for universalism. In addition, identifying as belonging to the majority Christian Orthodox denomination (a background variable) is shown to be associated with increased conformity and reduced self-direction. Such aspects of religiosity seem to be poor indicators for development, both at an individual level as well as at a collective and societal level. Moreover, the overall findings brought into view by the research model show that religiosity does not have much impact on promoting human rights, as only religious belief was found to positively influence support for human rights, and that of only one type (socioeconomic rights). Although socioeconomic rights are central to development, it can nevertheless be inferred that overall for this sample religiosity has a real but only limited potential impact in supporting and promoting a culture of sustainable development as described in the UN 2030 Agenda.

\section{Limitations and Further Research}

One of the limitations of the current study refers to the purposive sampling procedure that led to the inclusion of high school students, and thus limited the generalization of results. However, this population is considered to be the future elite of Romanian society and thus to have a 
potentially significant influence on the development of Romania. Another potential limitation, affecting comparisons with other nations, refers to the use of Likert scales. Previous research has indicated that people from different cultures may respond differently on the same scale, with some displaying a preference for extreme scoring (Hui and Triandis 1989). Such limitation is particularly relevant to this study, given, on the one hand, the currently high religiosity of the Romanian population, and on the other, its homogenous (Eastern Orthodox Christianity) character. This leaves out both the more secular nations, and those that are either religiously homogenous, but with a different majority tradition (i.e., Muslim, Hindu, Jewish or predominantly Catholic or Protestant), or religiously heterogenous cultures. Nevertheless, as with most academic work, one's own limitations can be turned into other's possible future research projects.

Moreover, the results of the present study indicate that there are other factors beyond religiosity that could contribute to variations in individual values, view of human dignity and support for human rights relevant to sustainable development. Future studies therefore should also take into account variables such as civic education, type of motivation, attachment style, parenting style, etc. In addition, mixed methodological approaches could look into the complexities of the socioeconomic and political contexts, including narratives, histories and practices that shape people's daily lives.

Supplementary Materials: The following are available online at http://www.mdpi.com/2077-1444/11/11/626/s1, SQ1: Religion and Human Rights Questionnaire, Table S1: Faith frequencies (\%), means and standard deviation, Table S2: Theism frequencies (\%), means and standard deviation, Table S3: Religious belief frequencies (\%), means and standard deviation, Table S4: Prayer frequencies (\%), means and standard deviation, Table S5: Religious service attendance frequencies (\%), means and standard deviation, Table S6: Individual value system frequencies $(\%)$, means and standard deviation, Table S7: Human dignity frequencies (\%), means and standard deviation, Table S8: Civil rights frequencies (\%), means and standard deviation, Table S9: Judicial rights frequencies (\%), means and standard deviation, Table S10: Political rights frequencies (\%), means and standard deviation, Table S11: Socioeconomic rights frequencies (\%), means and standard deviation, Table S12: Religious affiliation frequencies $(\%)$, Table S13: Religious socialization frequencies (\%), means and standard deviation, Table S14: Empathy frequencies (\%), means and standard deviation.

Author Contributions: Conceptualization, S.E.R.; methodology, S.E.R. and L.P.; validation, S.E.R.; formal analysis, L.P.; investigation, S.E.R.; data curation, L.P.; writing—original draft preparation, S.E.R.; writing-review and editing, S.E.R.; visualization, S.E.R. and L.P.; supervision, S.E.R.; project administration, S.E.R. Both authors have read and agreed to the published version of the manuscript.

Funding: This research received no external funding.

Acknowledgments: This article is dedicated to the kind memory of the Late Robert D. Reisz of West University of Timisoara, a highly respected colleague and close friend, with whom we shared many similar academic concerns. He left us unexpectedly, and way too early.

Conflicts of Interest: The authors declare no conflict of interest.

\section{References}

Alkire, Sabina. 2006. Religion and development. In The Elgar Companion to Development Studies. Edited by David Alexander Clark. Cheltenham: Edward Elgar, pp. 502-10.

Bates, Dana. 2013. The Glory of God Is Humanity Fully Alive: Exploring Eastern Orthodoxy as a Resource for Human Development in Conversation with the Capability Approach. Ph.D. thesis, Middlesex University, London, UK. Supervised by Silviu Rogobete and Severine Deneulin. Available online: http://eprints.mdx.ac .uk/13709/ (accessed on 10 January 2020).

Berger, Peter. 1969. The Sacred Canopy: Elements of a Sociological Theory of Religion. New York: Doubleday.

Berger, Peter. 1999. The desecularization of the world: A global overview. In The Desecularization of the World: Resurgent Religion and World Politics. Edited by Peter Berger. Grand Rapids: Eerdmans Publishing Company, pp. 1-18.

Berry, Evan. 2014. Religion and sustainability in global civil society. Worldviews: Global Religions, Culture, and Ecology 18: 269-88. [CrossRef]

Breskaya, Olga, and Silviu Rogobete. 2020. Religious freedom in context: A comparison between Belarus and Romania. In Global Eastern Orthodoxy. Edited by Giussepe Giordan and Sinisa Zrinščak. Cham: Springer, pp. 125-48. [CrossRef] 
Breskaya, Olga, Pal K. Botvar, Anders Sjöborg, and Silviu Rogobete. 2019. Religion, trust in institutions and attitudes towards abortion: A comparison of Lutheran and Orthodox Countries. In Euthanasia, Abortion, Death Penalty and Religion-The Right to Life and Its Limitations. Edited by Hans-Georg Ziebertz and Francesco Zaccaria. Cham: Springer, vol. 4, pp. 271-99. [CrossRef]

Brundtland, Gro. 1987. Our Common Future. Report of the World Commission on Environment and Development. Available online: https://sustainabledevelopment.un.org/content/documents/5987our-common-future.pdf (accessed on 10 January 2020).

Christie, Ian, Richard M. Gunton, and Adam P. Hejnowicz. 2019. Sustainability and the common good: Catholic social teaching and 'Integral Ecology' as contributions to a framework of social values for sustainability transitions. Sustainability Science 14: 1343-54. [CrossRef]

Davis, H. Mark. 1980. A multidimensional approach to individual differences in empathy. Catalog of Selected Documents in Psychology 10: 85. Available online: https://www.researchgate.net/publication/34891073_A_Mu ltidimensional_Approach_to_Individual_Differences_in_Empathy (accessed on 10 March 2020).

Davis, H. Mark. 1983. Measuring individual differences in empathy: Evidence for a multidimensional approach. Journal of Personal Social Psychology 44: 113-26. [CrossRef]

Deneulin, Severine, and Masooda Bano. 2009. Religion in Development: Rewriting the Secular Script. London: Zed. Donnelly, Jack. 1999. Human rights, democracy, and development. Human Rights Quarterly 21: 608-32. [CrossRef] Ekardt, Felix. 2020. Sustainability: Transformation, Governance, Ethics, Law. Cham: Springer Nature. [CrossRef]

Erikson, H. Erik, and Joan M Erikson. 1998. The Life Cycle Completed, Extended Version. New York: WW Norton \& Company.

Evans, Jonathan, and Chris Baronavski. 2018. How Do European Countries Differ in Religious Commitment? Pew Research Centre. Available online: www.pewresearch.org/fact-tank/2018/12/05/how-do-european-cou ntries-differ-in-religious-commitment/ (accessed on 10 December 2019).

Firoiu, Daniela, George H. Ionescu, Anca Băndoi, Nicoleta Mihaela Florea, and Elena Jianu. 2019. Achieving sustainable development goals (SDG): Implementation of the 2030 Agenda in Romania. Sustainability 11: 2156. [CrossRef]

Fukuda-Parr, Susan, Terra Lawson-Remer, and Sakiko Randolph. 2009. An index of economic and social rights fulfillment: Concept and methodology. Journal of Human Rights 8: 195-221. [CrossRef]

Fukuyama, Francis. 2014. NWC Global Education Centre. Available online: https://my.nwciowa.edu/ICSFileServ er/UserFiles/Uploads/boryana.dobreva/GEC_Newsletter_Issue_5.pdf (accessed on 5 January 2020).

Gas-Aixendri, Montserrat, and Silvia Albareda-Tiana. 2019. The role of religion in global sustainability: A study on Catalonia's contribution to sustainable development goals. In Sustainability and the Humanities. Edited by Walter Leal-Filho and Adriana Consorte-McCrea. Cham: Springer Nature. [CrossRef]

Grimm, Dieter. 2013. Dignity in a legal context: Dignity as an absolute right. In Understanding Human Dignity. Edited by Christopher McCrudden. Oxford: Oxford University Press, vols. 381-391.

Haynes, Jeffrey. 2007. Religion and Development: Conflict or Cooperation? London: Palgrave.

Hui, Harry C., and Harry C. Triandis. 1989. Effects of culture and response format on extreme response style. Journal of Cross-Cultural Psychology 20: 296-309. [CrossRef]

Ives, Christopher D., and Jeremy Kidwell. 2019. Religion and social values for sustainability. Sustainability Science 14: 1355-62. [CrossRef]

Juergensmeyer, Mark. 2000. Terror in the Mind of God: The Global Rise of Religious Violence. Berkeley: University of California Press.

Kass, Jared D., Richard Friedman, Jane Leserman, Patricia C. Zuttermeister, and Herbert Benson. 1991. Health outcomes and a new index of spiritual experience. Journal for the Scientific Study of Religion 30: 203-11. [CrossRef]

Kolakovski, Leszek. 1983. Marxism and human rights. Daedalus 112: 81-92.

Lazar, Anton. 2011. Religie si dezvoltare in Muntii Banatului. Cluj-Napoca: Risoprint.

Leal-Filho, Walter, Lena Maria Dahms, and Adriana Consorte-McCrea. 2019. Sustainability and religion: Past trends and future perspectives. In Sustainability and the Humanities. Edited by Walter Leal-Filho and Adriana Consorte-McCrea. Cham: Springer Nature.

Narayanan, Yamini. 2013. Religion and sustainable development: Analysing the connections. Sustainable Development 21: 131-39. [CrossRef]

Nordenfelt, Lennart. 2004. The varieties of dignity. Health Care Analysis 12: 69-81. [CrossRef] [PubMed] 
Nussbaum, Martha. 2003. Capabilities as fundamental entitlements: Sen and social justice. Feminist Economics 9: 33-59. [CrossRef]

Rakodi, Carole. 2015. Development, religion and modernity. In The Routledge Handbook of Religions and Global Development. Edited by Emma Tomalin. London: Routledge, pp. 17-35.

Randolph, Sakiko, Susan Fukuda-Parr, and Terra Lawson-Remer. 2010. Economic and social rights fulfilment index: Country scores and rankings. Journal of Human Rights 9: 230-61. [CrossRef]

RHR. 2011-2019. Religion and Human Rights. International Empirical Research. Available online: www.rhr.theo logie.uni-wuerzburg.de (accessed on 1 February 2020).

Rogobete, Silviu, and Ligia Vitelar. 2020. Religion and existential security: An empirical study of religion and socioeconomic rights amongst high-school learners in post-atheist, post-totalitarian Romania. In International Empirical Studies on Religion and Socioeconomic Human Rights. Edited by Hans-Georg Ziebertz and Carl Sterkens. Cham: Springer Nature, vol. 5, pp. 101-28. [CrossRef]

Rogobete, Silviu, and Robert Reisz. 2018. Religion, political and judicial rights in post-communist, post-atheist spaces. An empirical analysis among youth in Romania. In Political and Judicial Rights through the Prism of Religious Belief. Religion and Human Rights. Edited by Carl Sterkens and Hans-Georg Ziebertz. Cham: Springer Nature, vol. 3, pp. 95-121. [CrossRef]

Rogobete, Silviu. 2004. Morality and tradition in post-communist Orthodox lands: On the universality of human rights with special reference to Romania. Religion State and Society 32: 275-97. [CrossRef]

Romania Credincioasa. 2015. Percepții și Comportament Religios. Available online: www.ires.com.ro/articol/302/ romania-credincioasa--percep \%C8\%9Bii- \%C8\%99i-comportament-religios (accessed on 10 February 2020).

Saroglou, Vassilis, Vanessa Delpierre, and Rebecca Dernelle. 2004. Values and religiosity: A meta-analysis of studies using Schwartz's model. Personality and Individual Differences 37: 721-34. [CrossRef]

Schwartz, Shalom H, and Sipke Huismans. 1995. Value priorities and religiosity in four western religions. Social Psychology Quarterly 58: 88-107. [CrossRef]

Schwartz, Shalom H. 1992. Universals in the content and structure of values: Theoretical advances and empirical tests in 20 countries. In Advances in Experimental Social Psychology. Edited by Mark Zanna. Orlando: Academic Press, vol. 25, pp. 1-65.

Schwartz, Shalom H. 1994. Are there universal aspects in the structure and contents of human values? Journal of Social Issues 50: 19-45. [CrossRef]

Schwartz, Shalom H., and Lilach Sagiv. 1995. Identifying culture specifics in the content and structure of values. Journal of Cross-Cultural Psychology 26: 92-116. [CrossRef]

Sen, Amartya. 1980. Equality of What? In Tanner Lectures on Human Values. Edited by Sterling McMurrin. Cambridge: Cambridge University Press.

Sen, Amartya. 1982. Rights and agency. Philosophy \& Public Affairs 11: 3-39. [CrossRef]

Sen, Amartya. 1999. Development as Freedom. New York: Alfred Knopf Publishers.

Sen, Amartya. 2000. Human rights and human development. In UNDP Human Development Report 2000: Human Rights and Human Development. Chp. 1. pp. 19-26. Available online: http://www.hdr.undp.org/en/content/hu man-development-report-2000 (accessed on 1 February 2020).

Sen, Amartya. 2004. Elements of a theory of human rights. Philosophy \& Public Affairs 23: 315-56. [CrossRef]

Sen, Amartya. 2005. Human rights and capabilities. Journal of Human Development 6: 151-66. [CrossRef]

Stan, Lavinia, and Lucian Turcescu. 2007. Religion and Politics in Post-Communist Romania. Oxford: Oxford University Press.

Tismăneanu, Vladimir. 2003. Stalinism for All Seasons: A Political History of Romanian Communism. Oakland: University of California Press.

Tomalin, Emma, Jorg Haustein, and Shabaana Kidy. 2019. Religion and the sustainable development goals. The Review of Faith E International Affairs 17: 102-18. [CrossRef]

Tomalin, Emma. 2015. The Routledge Handbook of Religions and Global Development. London: Routledge.

UN 2030 Agenda for Sustainable Development. 2015. Available online: https://sustainabledevelopment.un.org/po st2015/transformingourworld (accessed on 10 September 2019).

UN Human Development Reports. 2019. Human Development Index. United Nations Development Programme. Available online: http://hdr.undp.org/en/content/2019-human-development-index-ranking (accessed on 10 January 2020). 
Unser, Alexander, Sussane Döhnert, and Hans-Georg Ziebertz. 2018. Attitudes towards refugee rights in thirteen countries. A multi-level analysis of the impact and interaction of individual and socio-cultural predictors. In Political and Judicial Rights through the Prism of Religious Belief. Religion and Human Rights. Edited by Carl Sterkens and Hans-Georg Ziebertz. Cham: Springer Nature, vol. 3, pp. 275-302. [CrossRef]

Vienna Declaration and Programme of Action. 1993. Available online: https://www.ohchr.org/EN/ProfessionalInt erest/Pages/Vienna.aspx (accessed on 1 February 2020).

Ziebertz, Hans-Georg, Sussane Döhnert, and Alexander Unser. 2018. Predictors of attitudes towards human dignity: An empirical analysis among youth in Germany. In Religion and Civil Human Rights in Empirical Perspective. Edited by Hans-Georg Ziebertz and Carl Sterkens. Cham: Springer Nature. [CrossRef]

Publisher's Note: MDPI stays neutral with regard to jurisdictional claims in published maps and institutional affiliations.

(C) 2020 by the authors. Licensee MDPI, Basel, Switzerland. This article is an open access article distributed under the terms and conditions of the Creative Commons Attribution (CC BY) license (http://creativecommons.org/licenses/by/4.0/). 